\title{
Poliomyelitis vaccination campaigns in Brazil resulting in the eradication of the disease (1961-1994)
}

\section{Dilene Raimundo do Nascimento}

I n 1994 Brazil received its certificate of poliomyelitis (polio) eradication. It was an achievement for the health sector that resulted not only in the eradication of a disease that caused great suffering throughout the lives of those who had it, but also contributed towards the development of a culture of preventing preventable diseases by immunization. The historical process of polio control and eradication clearly reveals the development and legitimization of national and international public health policies, the incorporation of new technologies, and medical practices and discursive constructions.

The aim here is to investigate the historical process concerning the policy for the control and eradication of polio in Brazil. Especially the vaccination campaigns held after the advent of the Salk and Sabin vaccines, and the National Vaccination Days, which constituted a model that was replicated in other parts of Latin America, resulting in the eradication of polio throughout the Americas. Another objective is to show that not only were these technologies prerequisites for the control and subsequent eradication of the disease in the country, but that political will and negotiation were also essential ingredients.

In the early twentieth century, developed countries with good sanitation conditions were struck by major epidemics of polio, posing a challenge to the prevailing view held by physicians and scientists that correlated the occurrence of infectious diseases with dirt $^{1}$. Yet in the case of polio, poor sanitation and hygiene actually made it easier for children to come into contact with the virus at a very early age, when they developed the disease in its mild form, resulting in immunity. In the first years of life, infection rarely produced serious symptoms, and was often mistaken for a cold. The better the sanitation and living conditions, the later

1 Naomi Rogers. Dirt and Disease: polio before FDR. New Brunswick, NJ, Rutgers University Press, 1996. 
children would come into contact with the virus and the higher their chances of developing paralysis ${ }^{2}$.

The poliomyelitis virus mainly infects children up to 5 years of age, and may be asymptomatic. However, in $1 \%$ of cases it causes the rapid onset of acute flaccid paralysis, generally of a lower limb, although it can also affect upper limbs and even the muscles used for breathing or swallowing, when it can lead to death. Difficulty standing and walking, muscle weakness, pain and fatigue are the most common complaints amongst children who have polio up to 5 years of age. The sequelae, mostly irreversible, tend to worsen with age.

Developed countries invested heavily in researching the disease and developing technologies to fight it $^{3}$. According to Nascimento and Maranhão, "it came clear that the virus multiplied in the gastrointestinal tract and that infection could be transmitted by the fecal-oral route, meaning that it was transmitted by water or substances contaminated by feces and ingested orally." ${ }^{\prime 4}$

Thanks to these discoveries and the use of new tissue culture techniques, the possibility of a vaccine became real's. In the 1950s two specific polio vaccines were produced: the Salk vaccine and the Sabin vaccine. By the mid-1960s, after these vaccines were approved in a process that involved intense debate to identify which one was more effective - to the point that one of the most heated topics at the $5^{\text {th }}$ International Poliomyelitis Conference in Copenhagen on July 26-28, 1960, was the relative merits of these two vaccines ${ }^{6}$ - the disease was no longer found in the countries where they were used en masse ${ }^{7}$.

In most industrialized countries that managed to obtain good immunization coverage using the Sabin and Salk vaccines, paralytic polio became almost unheard of. Some less developed countries, like Cuba and Costa Rica, managed to eliminate the disease by the end of the 1960s. In the U.S.A., the introduction of the Salk vaccine in 1955 resulted in a drop in the incidence of paralytic polio in the country,

2 Acute flaccid paralysis is the most characteristic clinical symptom of polio. In most cases, it affects the lower limbs. When it affects the chest muscles, it usually results in death because the patient is unable to breathe.

3 Naomi Rogers, 1996, op. cit.

4 Nascimento, Dilene R. and Maranhāo, Eduardo P. "Uma gota, duas doses: Criança sadia, sem paralisia", pp.229-241in: Dilene Raimundo do Nascimento \& Diana Maul de Carvalho, eds. Uma história brasileira das doenças. Brasília: Paralelo 14, 2004, p. 230.

5 Naomi Rogers, 1996, op. cit., p. 173; Nascimento \& Maranhão, 2004, op.cit., p. 230.

6 O Estado de São Paulo, July 27, 1960, p. 9.

7 Robbins, F. C. The History of Polio Vaccine Development. In: Plotkin, S. A. \& Orenstein, .W.A. (eds). Vaccines. Philadelphia: Saunders, 1999; Koprowski and Stanley, H. La histoire alternative de la vaccin oral. In: MOULIN, A.-M. (ed.). La aventure de la vaccination. Paris: Fayard, 1996. 
and this trend continued as of 1963 when it was largely replaced by the Sabin vaccine. By 1969 , only about a dozen cases were reported in the country. ${ }^{8}$

\section{Poliomyelitis in Brazil}

In Brazil, although there are records of cases of polio in the last few decades of the nineteenth century, the literature indicates an increase in the number of observed cases in the early twentieth century. The first records of outbreaks in Rio de Janeiro are from 1909 and 1911, described by Fernandes Figueira, director of the Polyclinic for Children (Policlínica de Crianças) and a pediatrician at the National Hospice for the Mentally Ill (Hospício Nacional de Alienados) at the time'. A report by another physician, Francisco de Salles Gomes Júnior, describes an outbreak of polio in Vila Americana, São Paulo state, where 17 children were affected between January 1 and April 30,1917. He observed that all the children were under 5 years of age and that the community could have been infected by people who had recently arrived from New York, where there were major epidemics between 1916 and $1918 .{ }^{10}$

In 1930, a number of sizeable epidemics were recorded in São Paulo and other state capitals in Brazil. As of 1950 outbreaks were also described in various towns in the interior of the country, and in 1953 Rio de Janeiro witnessed its biggest ever epidemic, at a rate of 21.5 cases per 100,000 inhabitants.

Brazil's polio records for the first half of the twentieth century are very sketchy, and are probably not a true representation of the magnitude of the problem there, since they were written sporadically by physicians based on their own observations. The disease was also not on the country's public health agenda. At this time, the only people discussing polio were medical professionals themselves, interested in understanding the scientific models that explained the disease and how it occurred in epidemics. ${ }^{11}$

8 Mackay H W, Fodor A R, Kokko U P. Viremia. Following the Administration of Live Poliovirus Vaccines. AM J Public Health 53:274, 1963.

9 Antônio Fernandes Figueira. Doença de Heine-Medin no Rio de Janeiro. Rio de Janeiro, Tipografia do Jornal do Comércio, 1911.

10 Francisco de Salles Gomes Júnior, Epidemia de polyomielite infantil em Villa Americana. São Paulo, Serviço Sanitário do Estado de São Paulo/Officinas Gráficas Olegário Ribeiro, 1919.

11 André Luiz Vieira de Campos. A história da poliomielite no Brasil antes da vacina: modelos, epidemias e dilemas. In: Dilene Raimundo do Nascimento (ed.). A história da poliomielite. Rio de Janeiro, Garamond, 2010. 
As of the 1950s, the acquisition of new technologies like the Salk and Sabin vaccines, the development of laboratory techniques for diagnosing the disease, ${ }^{12}$ the definition of the concept and implementation of disease surveillance procedures, ${ }^{13}$ and the design of vaccination strategies ${ }^{14}$ shifted the focus of discussion to the arena of public health and enabled the implementation of policies for controlling the disease in the country.

As soon as the Salk vaccine was authorized in the United States (1955), some pediatricians and state and municipal health departments in Brazil started to apply the vaccine, in the latter case in small-scale immunization campaigns. In 1960 the Sabin vaccine was introduced to Brazil, and with it the debate already ongoing in the United States about the relative advantages and disadvantages of the two vaccines.

In May 1961, the Guanabara state health secretary, Dr. Marcelo Garcia, evaluated the new and revolutionary discovery for the fight against polio": the Sabin vaccine. While he claimed that the results obtained by this vaccine were more promising than those obtained by the Salk vaccine, Garcia was clear that it could not be used immediately in Brazil because "its application should be made en masse and all at once, which requires complex public health planning".

Various medical forums occupied themselves with discussing the two vaccines, especially the Brazilian Society of Pediatrics (Sociedade Brasileira de Pediatria) and the Brazilian Society of Hygiene (Sociedade Brasileira de Higiene).

A month earlier, the minister of health under the Jânio Quadros administration, Edward Catete Pinheiro, had set up a commission of leading physicians to give their opinion on the advantages and disadvantages of the two polio vaccines. Its members were: Joaquim Travassos, director of the Oswaldo Cruz Institute (Instituto Oswaldo Cruz); José Martinho da Rocha, professor of pediatrics at the University of Brazil (Universidade do Brasil); Paulo de Góes, professor of microbiology at the same university; Oswaldo Pinheiro de Campos, orthopedist; Madureira Pará, virologist; Bichat de Almeida Rodrigues, director of the National Health Department, and Álvaro Aguiar, chairman of the Brazilian Society of Pediatrics. The commission opted for the Sabin vaccine, citing its lower cost, ease of administration (oral), more prolonged protective effect, and capacity to multiply

12 Schatzmayr, Hermann et al. "Erradicação da poliomielite no Brasil: a contribuição da Fundação Oswaldo Cruz". História, Ciências, Saúde - Manguinhos, vol.9(1) pp. 11-24, jan.-abr., 2002.

13 Thacker \& Berkelman. History of Public Health Surveillance. In: Public Health Surveillance. Edited by William Halperin \& Edward L. Backer Jr. Van Nostrand Reinhold, New York, 1992.

14 Risi Jr., João Batista. "Considerações sobre a consultoria prestada pelo doutor Sabin ao Ministério da Saúde - Esclarecimentos necessários em face das repercussões de seu afastamento”. Brasília, April 18, 1980.

15 Correio da Manhã, October 15, 1961, p. 3. 
in the digestive system, enabling the elimination of the vaccine-derived virus in the environment. ${ }^{16}$

Following the commission's recommendation, the Ministry of Health officially adopted the trivalent oral vaccine of live attenuated strains of the virus - the Sabin virus - and started its campaigns for the immunization of children in a few municipalities in the states of São Paulo and Rio de Janeiro.

\section{Polio Vaccination Campaigns}

In July 1961 a pilot experiment using the Sabin vaccine was run in three towns in the state of São Paulo - Santo André, São Bernardo and São Caetano - to vaccinate 25,000 children. A similar experiment was run in the city of Rio de Janeiro in September of the same year. ${ }^{17}$

"One drop, two doses: one healthy child free of paralysis" was the slogan under which the campaign was introduced to Rio de Janeiro. A total of 278 vaccination centers were set up throughout the city, manned by 2,500 volunteers and assisted by a variety of government and private institutions. The target was to vaccinate 500,000 children aged between four months and 6 years from October 16 to 21, $1961^{18}$. The campaign received daily coverage in the newspapers, which hailed it as a success and expressed the hope it would be made nationwide. They also reminded readers of the need for the children who received this first dose to take a second dose 60 days later to assure immunization.

Neither of these campaigns had the range or continuity needed to control the disease, mainly because of problems in the supply and distribution of the vaccines.

It was at this time that the laboratory technique for diagnosing polio was introduced to Brazil via the Oswaldo Cruz Institute - a technology of the utmost importance for obtaining a differential diagnosis from other forms of paralysis similar to acute flaccid paralysis, and for effectively diagnosing the type of virus and occurrence when there were outbreaks. ${ }^{19}$

Still in the 1960s, the concept of epidemiological surveillance was introduced. The main mentors and advocates of the power of surveillance as a public health tool were an American epidemiologist, Langmuir, and a Czech epidemiologist, Raska ${ }^{20}$. The World Health Organization (WHO) introduced the concept when, in 1965, it

16 Correio da Manhã, April 8, 1961, p. 3.

17 Cf. Nascimento and Maranhão, 2004, op. cit.

18 Correio da Manhã, October 15, 1961, p. 3

19 Schatzmayr, Hermann et al. "Erradicação da poliomielite no Brasil: a contribuição da Fundação Oswaldo Cruz". História, Ciências, Saúde - Manguinhos, 9(1) pp. 11-24, jan.-abr., 2002.

20 Thacker and Berkelman, 1992 
created an Epidemiological Surveillance Unit at the Division of Communicable Diseases. In Brazil, the Foundation for Special Public Health Services (Fundação de Serviços Especiais de Saúde Pública) created the Center for Epidemiological Investigations (Centro de Investigações Epidemiológicas) in 1968, making the notification of polio mandatory throughout the country.

Even after the acquisition of new technologies, the severity of the polio problem was yet to be overcome. It was known that only $1 \%$ of polio cases resulted in paralysis, but just one paralytic child implied high economic and social costs.

In 1971, after repeated outbreaks of the disease in different parts of the country, the Ministry of Health introduced the National Plan for the Control of Poliomyelitis, which was piloted in the state of Espírito Santo, then radiated out to 14 Brazilian states in 1972 and 1973. This was the first nationally coordinated attempt to control the disease in Brazil. It went on until 1974, when it was abandoned, and routine vaccination as part of primary healthcare was prioritized under the coordination of the National Immunization Program created in 1973.

This strategic shift was due to changes at the Ministry of Health. In 1974, under President Geisel, Paulo de Almeida Machado, from the Faculty of Public Health, University of São Paulo (Universidade de São Paulo), was appointed minister of health. His position was that the actions of health centers, routine health measures, and health education were the key to public health, and the campaigns were accordingly discontinued, and replaced with routine vaccination as part of the primary health system.

Epidemiological data indicate that routine vaccination was not enough to control polio, not least because most of the population did not have regular access to health services, which were unavailable in many parts of the country. In 1975, 3,600 cases of polio were notified - the highest incidence reported until then - and in the following four years there were outbreaks of the disease in almost every state of Brazil. $^{21}$

\section{National Vaccination Days}

It was only in 1980 that the Ministry of Health introduced a new strategy specifically for polio. In response to the seriousness of the problem in Brazil, which was even recognized in meetings held by the WHO to evaluate the disease in the Americas, and to the national repercussions of the epidemics in the south of the country in December 1979 - a region where high levels of vaccination were

21 João Baptista Risi Jr. "El control de la poliomielitis en el Brasil". In Simposio Internacional sobre el Control de la Poliomielitis. Publicación Científica de la OPS No484, pp. 147-151, 1985. 
maintained - the newly appointed health minister, Waldir Arcoverde, decided to tackle the issue of polio in Brazil head on.

There were epidemics in the southern states of Paraná and Santa Catarina, and, contradicting the findings of Rosenberg ${ }^{22}$, who argues that the authorities tend to deny the existence of epidemics when they first break out, the Paraná state secretary for health, Oscar Alves, appeared on the television to announce that there was indeed an epidemic, attributing it to the negligence of the federal government. Shockwaves spread around the country at the tail end of 1979. In his analysis of this attitude, Risi ${ }^{23}$ supports Rosenberg's position, saying that the Paraná state secretary for health "took an unusual political position; it would have been normal for the secretary to set up a campaign and say that the matter was under control." ${ }^{24}$

By this point in time, many epidemiological features of polio had already been studied - not just its spatial and temporal occurrence, but also other important variables such as age, prior vaccination status, type of poliovirus isolated, place of occurrence, and sequelae. It was clear that polio was endemic throughout Brazil, and was most common amongst unvaccinated children aged 0 to 4 , and especially between 6 months and 2 years of age, who lived in urban areas, with the main cause being type 1 poliovirus. ${ }^{25}$

These elements formed the foundations for the approach to the disease in Brazil. The basic strategy was already drawn up in the early days of January 1980: blanket vaccination of children aged 0 to 5 over a short period of time across the entire country, twice a year. ${ }^{26}$

There was some resistance to this plan. At the time, a national public health reform movement was calling for more primary care, and considered the campaign strategy counterproductive in terms of awareness-raising and educating the population about their routine healthcare needs. $\mathrm{Risi}^{27}$ comments that the WHO, which had held an international conference in Alma Ata, was also against the idea of a "national day," and Carl Taylor, a consultant in preparing the documents for this conference, was one of the strongest opponents. However, Brazil's military

22 Rosenberg, C. Explaining Epidemics and Other Studies in the History of Medicine. Cambridge, University Press, 1992.

23 João Baptista Risi Jr ran the National Secretariat for Basic Health Actions at the Ministry of Health, to which the vaccination program was linked.

24 João Baptista Risi Jr., testimonial, 2000. Memória da poliomielite: acervo de depoimentos orais. [ed.] Anna Beatriz de Sá Almeida, Dilene Raimundo do Nascimento, Laurinda Rosa Maciel. Rio de Janeiro, Fiocruz, 2005.

25 Risi, op. cit., 1980.

26 Roberto Becker, testimonial, 2002. Memória da poliomielite: acervo de depoimentos orais. [eds] Anna Beatriz de Sá Almeida, Dilene Raimundo do Nascimento, Laurinda Rosa Maciel. Rio de Janeiro, Fiocruz, 2005.

27 João Baptista Risi Jr, op. cit., 2000. 
government was interested in adopting social policies to bolster its legitimacy, and lent the proposal its unconditional support.

The Ministry of Health invited Albert Sabin to advise the team on how to improve the intervention model, as this was the strategy he himself recommended when his oral vaccine was to be used with the purpose of eliminating polio from a country. However, after accepting the job in Brazil, he started questioning the epidemiological data the ministry gave him on the disease in the country, and proposed new research to identify the prevalence of sequelae in schoolchildren, which would mean examining 1.400 .000 children to estimate the magnitude of the disease in the country and thence to define the best strategy to control it.

The ministry's specialists were convinced they had enough data to design a vaccination strategy, and also thought Sabin's proposal was unfeasible because it would demand considerable resources and time, delaying a particularly pressing measure. ${ }^{28}$

The unwillingness of the ministry to accept Sabin's advice led to a major falling out between the two parties, with Sabin withdrawing from the collaboration, resulting in considerable negative national and international repercussions for the ministry. Sabin wrote a letter to the president of Brazil, which was published in a mainstream newspaper, in which he stressed the need for accurate statistical data, since "as in military operations, imprecise information about the enemy can lead to disasters, with the same thing happening when one goes about fighting an epidemic disease". ${ }^{29}$

Waldir Arcoverde's position at the ministry was under fire, but he won the president's backing, who said that the "Sabin case [had] alerted the people" and "helped to raise social awareness about the problem of paralytic poliomyelitis and the need for mass vaccination." ${ }^{30}$ Arcoverde also believed that ultimately much of the scientific community had had their pride wounded by Sabin's criticisms, and would end up supporting the government's program to control polio on its National Vaccination Days.

To get political support for these vaccination days, Waldir Arcoverde had made a speech to the Chamber of Deputies on April 23, 1980. He summed up the epidemiological status of polio, and provided justifications for the idea of holding national vaccination days, stressing that "data published by the WHO show that after India, Brazil is the country that recorded the highest number of cases of polio in the world between 1976 and 1978," and that a "detailed analysis of the data provided by the epidemiological surveillance system indicates that the occurrence of

28 Risi Jr., op. cit., 1980.

29 O Globo, March 28, 1980:14.

30 Jornal do Brasil, March 22, 1980, "1º Caderno" supplement. 
poliomyelitis in the country will not be controlled if the only strategy is to maintain routine vaccination ${ }^{31}$." Concerning the control of polio in Brazil, he explained that:

[t] he adoption of a special polio vaccination strategy, namely, to hold annual campaigns on set days, is founded on the following reasons:

a) the administration of the oral poliomyelitis vaccine to the greatest possible number of children in the shortest possible space of time produces the extensive natural dissemination of the virus, which temporarily removes other enteric viruses capable of interfering in the multiplication of the vaccine-derived virus, hampering immune response to the vaccine;

b) the mass dissemination of the vaccine-derived virus by vaccinated children will also tend to immunize unvaccinated children, and those who, on the campaign day, have an intestinal infection caused by an enteric virus capable of preventing the multiplication of the vaccine-derived virus;

c) the administration of the Sabin vaccine does not require special techniques, and can be executed by any person from a community after receiving proper guidance;

d) mass vaccination on a single day fosters the widespread use of community resources and the intensive participation of volunteers, reducing the operating costs of the program;

e) broad-based community mobilization will enable the vaccination of larger numbers of children;

f) the effectiveness of this strategy has been proven in other developing countries, where poliomyelitis has been controlled;

g) the urgent need to control poliomyelitis deserves special attention by the public sector for reasons of a socio-economic order:

- improved housing, hygiene and basic sanitation, typical of cities, may be a factor that limits the spread of the wild virus, and could help propitiate the appearance of large numbers of people susceptible to the virus, with a consequently increasing risk of outbreak of epidemics;

${ }^{\circ}$ even in areas with precarious sanitation conditions, a high incidence of the disease has been reported, with occasional epidemics breaking out when these areas receive flows of migrants with high percentages of susceptible people;

${ }^{\circ}$ the psychosocial impact caused by outbreaks of poliomyelitis is extremely harmful, in view of the dramatic nature of the disease;

${ }^{\circ}$ the cases of paralysis generally have permanent sequelae and constitute a high burden on society, accounting for much of the demand for physical rehabilitation services. ${ }^{32}$

In the same speech, the minister reported on his difference of opinion with Sabin, concluding that "disagreements about the evaluation needs and the methodology

31 Exposição do Ministro da Saúde, Dr. Waldyr Mendes Arcoverde, na Câmara dos Deputados. Brasília, 1980, p. 3.

32 Ibid., pp. 4-5. 
used led to relations being severed. Dr. Sabin abandoned his consultancy for the Ministry of Health ${ }^{33}$."

The first National Vaccination Day was eventually held in June 1980. According to Mozart Abreu Lima ${ }^{34}, 20$ million children were vaccinated. "The population was galvanized in mass; it was a celebration of Brazilian society. ${ }^{\prime 35}$ Consequently, the number of cases of the disease dropped sharply, from 1,290 in 1980 to 122 in 1981. The following year, the lowest ever number of confirmed cases of polio was reported: just 45. The National Vaccination Day strategy was repeated every year, and the number of cases dropped close to zero.

Public recognition of the National Vaccination Days was the ultimate approval of this strategy, which is still employed systematically in the country. In the 1980s and 90 s - a period marked by political instability and administrative discontinuity with dire repercussions for the health sector - this strategy stands out as an exception.

It subsequently took on an international dimension when the Pan-American Health Organization (PAHO) recommended it as the model for interrupting the transmission of wild poliovirus in the Americas - i.e. the eradication of poliomyelitis in the whole continent.

\section{The Polio Eradication Process}

In the field of public health, a number of different concepts of eradication have been debated. First contemplated in the nineteenth century as new scientific knowledge emerged about the causes and transmission mechanisms of different diseases, the term eradication has been given different definitions over time, leading Alfred Evans ${ }^{36}$ to suggest that the real global eradication of notifiable diseases is more myth than reality. ${ }^{37}$

Another epidemiologist, Yekutiel, has proposed six preconditions for eradication programs: 1) control measure completely effective in breaking transmission, simple in application, and relatively inexpensive; 2) the disease should have epidemiological features allowing timely and effective case detection and surveillance in the advanced stages of the program; 3) the disease must be of

33 Ibid., p. 9.

34 Mozart Abreu Lima was the general secretary of the Ministry of Health.

35 Mozart Abreu Lima, testimonial, 2002. Memória da poliomielite: acervo de depoimentos orais. eds Anna Beatriz de Sá Almeida, Dilene Raimundo do Nascimento, Laurinda Rosa Maciel. Rio de Janeiro, Fiocruz, 2005.

36 Alfred Evans is an epidemiologist at the Department of Epidemiology and Public Health, Yale University School of Medicine, New Haven, Connecticut, USA.

37 Evans, Alfred, "The eradication of communicable diseases: myth or reality?" American Journal of Epidemiology, 122(2), pp. 199-207, 1985. 
recognized national or international socio-economic importance; 4) there should be a specific reason for eradication rather than control of the disease; 5) there should be sufficient financial and administrative capacity and health service resources; and 6) there should be the necessary socioecological conditions. ${ }^{38}$

In Evans's opinion, these preconditions did not apply to any disease at the beginning of the 1980s: while the global eradication of smallpox was hailed as a marvelous achievement, it could not apply to any other disease. Different specialists involved in the smallpox eradication campaign agreed with this view. The received opinion at the time was that important lessons could be learnt from the eradication of smallpox, but that these would not lead to another disease being picked for global eradication.

Donald Henderson ${ }^{39}$, who spearheaded the smallpox eradication campaign, did not believe polio could be eradicated because of two main issues: the difficulty of detecting the presence of the polio virus in a given region ("a patient with paralysis caused by polio is only the tip of the iceberg that is infection in the community"), and the fact that the polio vaccine may not be as thermostable as the smallpox one $e^{40}$.

Frank Fenner, an internationally renowned virologist and leader of the team that evaluated the smallpox program, commented in a speech about eradication in the early 1980s that "were this meeting to limit itself to other candidates for immediate global eradication, we might as well pack up and go home". ${ }^{4}$

However, at the PAHO and Unicef, ${ }^{42}$ the need to bolster the credibility of immunization strategies was on the discussion agenda, building on the success of the global eradication of smallpox. The decision was therefore taken to eradicate polio in the Americas, since several countries had already had some success in its control. Uruguay, Chile, Venezuela and Argentina had all run vaccination campaigns in a short space of time, the Argentinean campaign being the largest, vaccinating 20 million children on each national vaccination day. Brazil, with its continental scale, had vaccinated 20 million children on each of its National Vaccination Days.

The repercussions of this achievement were great, not just for the impact on the incidence of polio in the country, but also because it showed the feasibility of the strategy of vaccinating the whole population on a single day, as expounded by

38 Yekutiel, P. Eradication of Infectious Diseases. A critical study. New York, Karger, 1980.

39 Donald Henderson ran the WHO's Smallpox Eradication Program from 1966 to 1977.

40 Donald Henderson. "Como é que a varíola mostrou o caminho". A Saúde no Mundo, Organização Mundial de Saúde, pp. 19-21, 1989, p.20.

41 Evans, op. cit., 1985, p. 204.

42 James P. Grant (1922-1995) became executive director of Unicef in January 1980. As of 1982 he was responsible for major investments by Unicef in its Universal Childhood Immunization program to fight what he called the "silent global emergency" that was the death of millions of children of preventable diseases. 
Sabin. This reinforced the PAHO's decision to design a strategy for the disease in the whole of the Americas.

Having acquired "strong enough political will," 43 the PAHO announced its target of interrupting the transmission of wild poliovirus in the Americas by 1990, disregarding the opinion of international authorities who had taken part in the smallpox program.

At the $31^{\text {st }}$ meeting of the PAHO's Directing Council in September 1985, the member countries approved and committed to this initiative. In Brazil, breaking the transmission of wild poliovirus was included in the social priorities of Brazil's post-military government in 1986.

Although the modern concept of eradication ${ }^{44}$ established at the $1^{\text {st }}$ International Conference on Disease Eradication in 1980 implies a global reach, the controversies over the use of the concept persist, and the proposal to interrupt the transmission of wild poliovirus in the Americas, despite its regional footprint, came to be regarded as an eradication program.

As Moulin $^{45}$ explains, immunization is an extremely complex act, involving laboratories, the pharmaceutical industry, national and international policies, the perception of the disease to be prevented, rights and protection of liberties, among other aspects. The "adventure of vaccination" could not exist without political validation and the activation of a type of social compact.

And just such a compact was established between the PAHO, Unicef, the InterAmerican Development Bank (IDB), USAID, Rotary International, and the governments of all the countries in the continent. The participation of international agencies was fundamental for the success of the proposal to eradicate the transmission of wild poliovirus in the Americas.

The role of Rotary International is particularly worthy of note in global efforts to eradicate polio. In 1985 it set up a program called Polio Plus to help with the immunization of all the children in the world, first until 2005, but since then until the disease has been wiped out. Not only is it the biggest non-governmental donor, but hundreds of thousands of its volunteers around the world have helped deliver the vaccines, mobilize society, and provide logistical planning. These voluntary efforts by Rotarians were extremely valuable in eradicating polio in the Americas.

In 1986, a working group for polio eradication was set up in Brazil, tasked with making vaccination coverage more efficient, improving the quality of the surveillance of the epidemiological behavior of poliomyelitis, and establishing

43 Evans, 1985, op. cit., p. 199.

44 "Eradication of an infection means that the infection has disappeared completely from all countries in the world because transmission of the causative organism has ceased completely." (Reviews of Infectious Diseases, 4(5), sept/oct.1982. p. 16).

45 Anne Marie Moulin (ed.) L'Aventure de la vaccination. Paris, Fayard, 1996. 
whatever control measures were needed, with adequate oversight and evaluation processes.

The polio eradication program was built on two pillars: increasing immunization in order to attain and maintain high, homogeneous vaccination coverage (around 90\%), and new or expanded disease surveillance activities and measures for controlling outbreaks.

In response to the cases it investigated and new clinical and epidemiological knowledge produced on the disease, the program reviewed and modified its surveillance concepts and methods. One new measure was to create clinical evaluation commissions of neurologists to identify cases of polio in the absence of stool samples.

In March 1989 the last case of wild poliovirus was notified in the country, in the municipality of Souza, Paraíba state. ${ }^{46}$ As of 1990 , while maintaining the strategies it had used thus far to eradicate polio, Brazil reoriented the program towards fulfilling the criteria established by the International Commission for the Certification of Poliomyelitis Eradication.

This commission convened in Washington in August 1994, where it declared that wild poliovirus transmission had been interrupted in the Americas. Polio had been eradicated from Brazil.

\section{Concluding Comments}

While Brazil's polio vaccination campaigns failed to cover the whole country and to be run consistently without breaks, they were unable to control the disease in the country. The National Vaccination Day strategy proved an effective policy for fighting polio in Brazil with the objective of controlling it.

After the National Vaccination Days earned public recognition, they were employed as a strategy that has survived to this day. They acquired an international dimension when the Pan-American Health Organization recommended them as a model for interrupting wild poliovirus transmission in the Americas; i.e., the effective eradication of poliomyelitis in the region.

To eradicate the disease, sufficient political will was needed in intergovernmental negotiations to get all the stakeholders behind the idea of running an Americaswide campaign. This immunization campaign was led by the PAHO in conjunction with Unicef, the IDB and Rotary International, and was showcased as an example of partnership between the public and private sectors and community engagement in public health activities.

46 The last case of polio in the Americas was in Peru in June 1991. 
The policy to eradicate polio from the Americas was a successful health strategy that involved the engagement of several sectors of civil society, and brought gains beyond the eradication of the disease, such as the strengthening of vaccination programs, which were expanded considerably and had new vaccines included, and the development of a culture of prevention in society.

Dilene Raimundo do Nascimento, is researcher and professor in the Graduate Program in the History of Science and Health at Casa de Oswaldo Cruz, Fundação Oswaldo Cruz. 


\section{References}

Abreu, M. Lima, testimonial, 2002. Memória da poliomielite: acervo de depoimentos orais. eds de Sá Almeida, A. B., Nascimento, D.R. \& Maciel, L. R.. (Rio de Janeiro, Fiocruz, 2005).

Becker, R. testimonial, 2002. Memória da poliomielite: acervo de depoimentos orais. eds Anna Beatriz de Sá Almeida, Dilene Raimundo do Nascimento, Laurinda Rosa Maciel. (Rio de Janeiro, Fiocruz, 2005).

Correio da Manhä, October 15, (1961), p. 3.

Correio da Manhã, April 8, (1961), p. 3.

Evans, A., "The eradication of communicable diseases: myth or reality?" American Journal of Epidemiology, 122(2), (1985), pp 199-207.

Exposição do Ministro da Saúde, Dr. Waldyr Mendes Arcoverde, na Câmara dos Deputados. (Brasília, 1980)

Figueira, A. F., Doença de Heine-Medin no Rio de Janeiro. Rio de Janeiro, Tipografia do Jornal do Comércio, (1911).

Henderson, D. "Como é que a varíola mostrou o caminho". A Saúde no Mundo, Organização Mundial de Saúde, pp. 19-21, (1989), p. 20.

Jornal do Brasil, March 22, 1980, "10 Caderno" supplement

Koprowski and Stanley, H. La histoire alternative de la vaccin oral. In: Moulin N, A.-M. ed. La aventure de la vaccination. (Paris: Fayard, 1996).

Mackay H W, Fodor A R, Kokko U P. Viremia. Following the Administration of Live Poliovirus Vaccines. AM J Public Health 53(274) (1963).

Moulin, A.M. (ed.) L'Aventure de la vaccination. (Paris, Fayard, 1996).

Nascimento, D. R. and Maranhāo, E. P. "Uma gota, duas doses: Criança sadia, sem paralisia”, pp.229-241, in: Nascimento, D.R. \& Carvalho D.M. eds Uma história brasileira das doenças. Brasília: Paralelo 14, (2004), p. 230.

O Estado de São Paulo, July 27, (1960), p. 9.

O Globo, March 28, 1980:14.

Risi Jr., J. B., "Considerações sobre a consultoria prestada pelo doutor Sabin ao Ministério da Saúde - Esclarecimentos necessários em face das repercussões de seu afastamento". Brasília, April 18, (1980).

Risi Jr., J. B. testimonial, 2000. Memória da poliomielite: acervo de depoimentos orais. (ed.) Anna Beatriz de Sá Almeida, Dilene Raimundo do Nascimento, Laurinda Rosa Maciel. (Rio de Janeiro, Fiocruz, 2005).

Robbins, F. C. The History of Polio Vaccine Development. In: Plotkin, S. A. \& Orenstein, W. A. eds. Vaccines. (Philadelphia: Saunders, 1999).

Rogers, N.. Dirt and Disease: polio before FDR. New Brunswick, NJ, (Rutgers University Press, 1996). 
Rosenberg, C. Explaining Epidemics and Other Studies in the History of Medicine. (Cambridge, University Press, 1992).

Salles Gomes Júnior, F. Epidemia de polyomielite infantil em Villa Americana. São Paulo, Serviço Sanitário do Estado de São Paulo/Officinas Gráficas Olegário Ribeiro, (1919).

Schatzmayr, H. et al. "Erradicação da poliomielite no Brasil: a contribuição da Fundação Oswaldo Cruz". História, Ciências, Saúde - Manguinhos, 9(1), 1124, jan.-abr., (2002).

Thacker \& Berkelman. History of Public Health Surveillance. In: Public Health Surveillance. Edited by William Halperin \& Edward L. Backer Jr. Van Nostrand Reinhold, (New York, 1992).

Vieira de Campos, A.L. A história da poliomielite no Brasil antes da vacina: modelos, epidemias e dilemas. In: Nascimento, D.R. ed. A história da poliomielite. (Rio de Janeiro, Garamond, 2010).

Yekutiel, P. Eradication of Infectious Diseases. A critical study. (New York, Karger, 1980). 